\title{
Article \\ Effect of Sodium-Containing Fluxes on the Residual Sodium Content and Distribution in Al-Mg Alloys
}

\author{
Chunfa Huang ${ }^{1,2,3,4}$, Zhiguo Liu ${ }^{1,2,3}$, Jianxian Huang ${ }^{4}$, Qiwen Liu ${ }^{5}$ and Jianguo Li ${ }^{4, *}$ \\ 1 General Research Institute for Nonferrous Metals, Beijing 100088, China; huangchunfa2012@163.com (C.H.); \\ zhgliu@grinm.com (Z.L.) \\ 2 GRIMAT Engineering Institute Co., Ltd., Beijing 101407, China \\ 3 State Key Laboratory of Advanced Materials for Smart Sensing, GRINM Group Co., Ltd., \\ Beijing 100088, China \\ 4 Laboratory of Advanced Materials, School of Materials Science and Engineering, Tsinghua University, \\ Beijing 100084, China; hjx17@tsinghua.org.cn \\ 5 Yingkou Zhongwang Aluminum Co., Ltd., Yingkou 111003, China; lqwliuqiwen@163.com \\ * Correspondence: jg.li@mail.tsinghua.edu.cn; Tel.: +86-010-6279-1092
}

Citation: Huang, C.; Liu, Z.; Huang, J.; Liu, Q.; Li, J. Effect of SodiumContaining Fluxes on the Residual Sodium Content and Distribution in Al-Mg Alloys. Metals 2021, 11, 1591. https://doi.org/10.3390/met11101591

Academic Editor: Soran Birosca

Received: 26 August 2021

Accepted: 4 October 2021

Published: 7 October 2021

Publisher's Note: MDPI stays neutral with regard to jurisdictional claims in published maps and institutional affiliations.

Copyright: (c) 2021 by the authors. Licensee MDPI, Basel, Switzerland. This article is an open access article distributed under the terms and conditions of the Creative Commons Attribution (CC BY) license (https:// creativecommons.org/licenses/by/ $4.0 /)$.

\begin{abstract}
To get an insight into the residual sodium content of $\mathrm{Al}-\mathrm{Mg}$ alloys, three types of sodiumcontaining fluxes were introduced into the melt with different magnesium content. The increment, existing form and distribution of sodium in Al-Mg alloys with different magnesium content were analyzed. The results show that the influence of different sodium salts on the increment of sodium in Al-10Mg alloy is significantly different. The $\mathrm{NaF}$ raised the sodium level in $\mathrm{Al}-10 \mathrm{Mg}$ alloy to the highest extent, $\mathrm{Na}_{3} \mathrm{AlF}_{6}$ coming second, and $\mathrm{NaCl}$ did not have an obvious influence. The magnesium element in the aluminum melt was found to be the key factor leading to the increment of sodium level. After the salt fluxing treatment of aluminum alloy with different magnesium content, this increment would be proportional to the content of magnesium. EDS mapping indicates the sodium introduced by the fluxes was distributed in the form of Na-rich particles in $\mathrm{Al}-\mathrm{Mg}$ alloys and preferentially located near $\mathrm{Al}_{3} \mathrm{Mg}_{2}(\beta)$ phase in the situation of high magnesium content.
\end{abstract}

Keywords: Al-Mg alloy; sodium-containing fluxes; residual sodium content; distribution; sodiuminduced brittleness

\section{Introduction}

Oxide inclusions are usually considered as one of the fundamental defects detrimental to the performances of aluminum alloys. To date, the most widely accepted and frequently adopted method to remove oxide inclusions from molten aluminum is fluxing treatment. Most salt fluxes are based on the $\mathrm{NaCl}-\mathrm{KCl}$ or the $\mathrm{KCl}-\mathrm{MgCl}_{2}$ binary systems. Additives include other chlorides, fluorides, nitrates, carbonates or sulphates [1]. In the process of fluxing treatment, the salt fluxes are injected into the melt to absorb the inclusions, then float to the surface of the molten aluminum. When the salt fluxes are brought in contact with molten aluminum, the aluminum will pick up some impurities due to the exchange reactions between the fluxes and the melt [1].

$\mathrm{Al}-\mathrm{Mg}$ alloy ingots with magnesium content higher than 2 wt.\% often suffer from brittle fracture during the deformation process at high temperatures $\left(200 \sim 400{ }^{\circ} \mathrm{C}\right)$ due to the high sodium content $(>10 \mathrm{ppm})$ [2-4]. In the production process of this type of aluminum alloy, it is necessary to control the sodium content to avoid high-temperature brittleness [5]. To avoid introducing the sodium in the smelting process, factories always choose more expensive sodium-free fluxes instead of sodium-containing fluxes in the production of Al-Mg alloys (especially for those with high magnesium content), thereby increasing production costs. However, Tremblay [6] found that the sodium content was less than $3 \mathrm{ppm}$ in the $\mathrm{Al}-5 \mathrm{Mg}$ alloys fluxed with fluxes containing $\mathrm{NaCl}$. It was implied that not all sodium components in the fluxes will significantly increase the sodium content 
of the alloys. At present, $\mathrm{NaCl}, \mathrm{NaF}$ and $\mathrm{Na}_{3} \mathrm{AlF}_{6}$ are among the most widely used sodium salts in the production of fluxes. $\mathrm{NaCl}$ is the basic component of the $\mathrm{NaCl}-\mathrm{KCl}$ system fluxes, while $\mathrm{NaF}$ and $\mathrm{Na}_{3} \mathrm{AlF}_{6}$ are considered to be effective components for the removal of nonmetallic oxide inclusions $[7,8]$, and they are widely used in the smelting of recycled aluminum. In order to further clarify the principle of composition design of flux for $\mathrm{Al}-\mathrm{Mg}$ alloy, it is necessary to study the influence of different sodium-containing fluxes on the residual sodium content of aluminum alloys with high magnesium content.

Some achievements have been made in the study of the existing form and distribution of sodium and the mechanism of high-temperature brittleness in Al-Mg alloys. Ransley [4] suggested that magnesium dissolves in the matrix in $\mathrm{Al}-\mathrm{Mg}$ alloys with magnesium content less than $2 \mathrm{wt} . \%$, while sodium exists as a ternary compound (AlSiNa); Once the magnesium content is increased to a higher level, magnesium will form $\mathrm{Mg}_{2} \mathrm{Si}$ phase as a result of incorporation with the impurity silicon in the alloy, while sodium exists in the form of free atoms. However, the existing form of sodium in Al-Mg alloys with different magnesium contents have not been confirmed experimentally. Horikawa [9] proposed that the elongation of $\mathrm{Al}-\mathrm{Mg}$ alloys with low magnesium content is not affected by sodium. When the magnesium content is higher than $2 \mathrm{wt} . \%$, the alloys with trace sodium gradually become brittle. This phenomenon was attributed to the trace sodium segregate on the grain boundary to form a sodium film, thereby leading to a decrease in the strength of the grain boundary during high-temperature deformation. However, no sodium film was detected on the grain boundaries in that research. Lynch [10] denied the distribution of sodium in $\mathrm{Al}-\mathrm{Mg}$ alloys as mentioned earlier. He considered that sodium probably clustered as particles instead of films, but it was a hypothesis. In addition, Feng [11] suggested that sodium introduced by flux is enriched on the grain boundary of $\mathrm{Al}-\mathrm{Cu}$ alloy, reducing the bonding force between the matrix and $\mathrm{CuAl}_{2}$ phase. Sweet [12] observed that sodium exists as discrete particles on the grain boundary in $\mathrm{Al}-\mathrm{Li}$ alloy.

Thus far, the existing form and distribution of sodium in Al-Mg alloys have still been controversial, and there are few studies on the effect of sodium salt in fluxes on the residual sodium content in $\mathrm{Al}-\mathrm{Mg}$ alloys. In this paper, the influence of different sodium salt components and the addition volume of fluxes on the content of residual sodium in $\mathrm{Al}-\mathrm{Mg}$ alloy was studied, and the existing form and distribution of sodium in Al-Mg alloy were analyzed. The present study aims to provide an experimental basis for the design of appropriate salt fluxes used for Al-Mg alloys. Furthermore, it intends to shed a light on ways to avoid high-temperature brittleness.

\section{Materials and Methods}

The raw materials used in the experiment were commercial $\mathrm{Al}$ and $\mathrm{Mg}$ ingots, both with a purity of $99.7 \%$. Al-Mg alloys with different magnesium contents were prepared according to the designed ratio. All input materials for preparing the fluxes used in the present experiment were chemically pure. They were mixed and melted by a certain ratio, and subsequently broken into fine particles after cooling. The compositions of fluxes are shown in Table 1.

Table 1. The component of salt fluxes.

\begin{tabular}{cc}
\hline Flux Name & Component \\
\hline $\mathrm{NK}$ & $50 \mathrm{wt} . \% \mathrm{NaCl}+50 \mathrm{wt} . \% \mathrm{KCl}$ \\
$\mathrm{NK}-\mathrm{Na}_{3} \mathrm{AlF}_{6}$ & $47.5 \mathrm{wt} . \% \mathrm{NaCl}+47.5 \mathrm{wt} \% \mathrm{KCl}+5 \mathrm{wt} . \% \mathrm{Na}_{3} \mathrm{AlF}_{6}$ \\
$\mathrm{NK}-\mathrm{NaF}$ & $47.5 \mathrm{wt} . \% \mathrm{NaCl}+47.5 \mathrm{wt} . \% \mathrm{KCl}+5 \mathrm{wt.} \% \mathrm{NaF}$ \\
\hline
\end{tabular}

The prepared Al-Mg alloys were melted and held at $740{ }^{\circ} \mathrm{C}$ in a resistance furnace, and the fluxes were added into the melts at the amount of $0.3,1.5,5$, and $10 \mathrm{wt} . \%$ of the alloys, respectively. The melt was held for $15 \mathrm{~min}$ after fluxing and the dross was skimmed before pouring into the steel mold. 
The samples for analysis were cut along the longitudinal section at the center plane of the as-cast ingot and followed by mechanical polishing. During the preparation, Anhydrous ethanol is used as a cleaning and cooling medium; the samples must not be contaminated by water, because the sodium will react with the water. The chemical composition of the $\mathrm{Al}-\mathrm{Mg}$ alloy ingots was analyzed by SPECTROMAXx spark spectrometer (Spectro, Kleve, Germany). A Hitachi-SU8220 scanning electron microscope (Hitachi High-Tech Corporation, Tokyo, Japan) integrating with a flat-Quad EDX (SEM, Hitachi High-Tech Corporation, Tokyo, Japan) was used to analyze the morphology and composition of the samples; the acceleration voltage used was $5 \mathrm{KV}$.

\section{Results and Discussions}

\subsection{Effect of Different Sodium-Containing Fluxes on the Residual Sodium Content in Al-10Mg Alloys}

As can be seen from Figure 1, all fluxes cause an increase in the sodium content in $\mathrm{Al}-10 \mathrm{Mg}$ alloy after refining. However, there is a divergence upon the extent of increment for different fluxes. The initial sodium content in Al-10Mg alloy was $2.8 \mathrm{ppm}$, which increased to $7.9 \mathrm{ppm}$ after $0.3 \mathrm{wt}$ \% NK flux was added. When the addition amount was increased to $10 \mathrm{wt} . \%$, the sodium content reached $18.2 \mathrm{ppm}$. When the flux was changed to $\mathrm{NK}-\mathrm{NaF}$, the sodium in the Al-10Mg increased remarkably. Even though at an addition of $0.3 \mathrm{wt} . \%$, the sodium level in the alloy soared to $35.1 \mathrm{ppm}$, significantly exceeding the critical sodium content (10 ppm) that would cause high-temperature brittleness. When the added amount of $\mathrm{NK}-\mathrm{NaF}$ flux reached $10 \mathrm{wt} . \%$, the sodium content in the $\mathrm{Al}-10 \mathrm{Mg}$ alloy dramatically increased up to 264 ppm, approximately 15 times larger than that of melt refined by NK flux under the same conditions. The $\mathrm{NK}-\mathrm{Na}_{3} \mathrm{AlF}_{6}$ flux posed a modest influence on the sodium content, which increased steadily over the addition from 0.3 to $1.5 \mathrm{wt} . \%$ and then stayed unchanged, similar to NK flux.

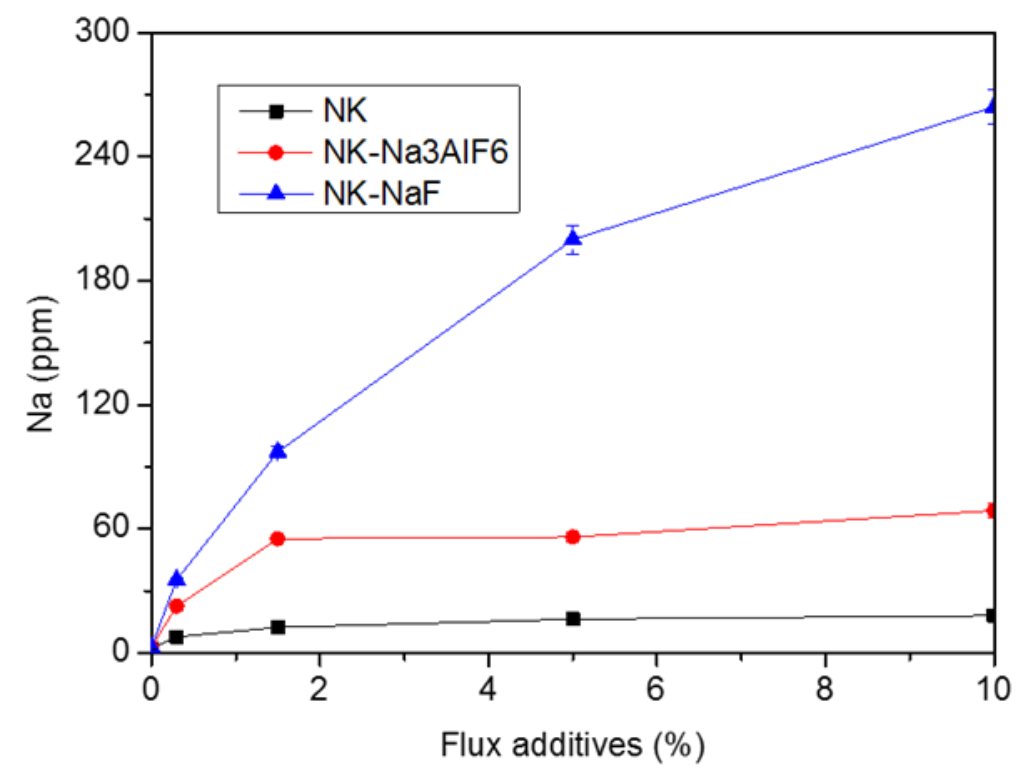

Figure 1. Effect of different sodium-containing fluxes on the residual content of sodium in $\mathrm{Al}-10 \mathrm{Mg}$ alloy.

The reason for the increase in sodium content in the alloy can be ascribed to the chemical reaction between the sodium component of the flux and alloying elements in the alloy. $\mathrm{NaCl}$ can react with $\mathrm{Al}$ and $\mathrm{Mg}$ in the melt to produce sodium [13], and the equilibrium constants of reactions at $740{ }^{\circ} \mathrm{C}$ are, respectively, $6.08 \times 10^{-24}$ and $1.01 \times 10^{-8}$ [14]. It can be seen that the increase in sodium was mainly caused by the reaction of $\mathrm{Mg}$ and $\mathrm{NaCl}$ because the smaller the reaction equilibrium constant is, the less the amount of sodium introduced is. Tremblay [6] used, respectively, $6.7 \mathrm{wt} . \% \mathrm{NaCl}$ and $1 \mathrm{wt} . \%\left(\mathrm{NaCl}-\mathrm{MgCl}_{2}\right)$ flux to refine $\mathrm{Al}-5 \mathrm{Mg}$. After refining, the sodium content of the alloy was less than $3 \mathrm{ppm}$, 
which was lower than that of the Al-10Mg alloy added with $0.3 \mathrm{wt} . \%$ NK flux in our experiment. We suggest that the higher magnesium content was responsible for the higher sodium increment since the high concentration of reactant proceeded the reaction in the forward direction. Furthermore, $\mathrm{MgCl}_{2}$ can effectively remove alkali metals and alkali earth metals in the aluminum melt [15]. Hence, a small amount of sodium produced by the reaction of $\mathrm{NaCl}$ and $\mathrm{Mg}$ could be removed by $\mathrm{MgCl}_{2}$. However, $\mathrm{KCl}$ in $\mathrm{NK}$ flux could not effectively remove the sodium. As a consequence, the Al-5Mg alloy in Tremblay's experiment had a lower residual sodium content than the present study. During the aluminum alloy smelting process, the amount of flux used is generally in the range from 0.05 to $0.5 \mathrm{wt} . \%$, while the accumulative amount of flux is sometimes multiplied to $1 \sim 15 \mathrm{wt} . \%$ in the waste aluminum recycling process due to the different types of input materials and treatment processes [16,17]. The sodium content in the Al-10Mg alloy fluxed by $0.3 \mathrm{wt} . \% \mathrm{NK}$ flux is lower than that which causes high-temperature brittleness. $\mathrm{NaCl}$ can induce a slight amount of sodium increase in Al-Mg alloy with a high magnesium concentration, but it is not enough to cause high-temperature brittleness under the normal addition amount of flux in primary aluminum production.

$\mathrm{NaF}$ can also react with $\mathrm{Al}$ and $\mathrm{Mg}$ in the melt, and the equilibrium constants of reactions at $740{ }^{\circ} \mathrm{C}$ are $6.95 \times 10^{-9}$ and 3.59 , respectively. Compared to the $\mathrm{NaCl}$, it is clear that the reaction between $\mathrm{NaF}$ and $\mathrm{Mg}$ is much easier, which indicates a higher increment of sodium. When using $\mathrm{NK}-\mathrm{Na}_{3} \mathrm{AlF}_{6}$ flux, the sodium content in the Al-10Mg alloy is significantly higher than that of $\mathrm{NK}$ flux. The reason is that $\mathrm{Na}_{3} \mathrm{AlF}_{6}$ would partially ionize into $\mathrm{NaF}$ and $\mathrm{AlF}_{3}$ in the molten state at high temperature [18], and then $\mathrm{NaF}$ reacted with $\mathrm{Mg}$ to form free sodium. Therefore, $\mathrm{NaF}$ is the key factor causing the increase in sodium in $\mathrm{Al}-\mathrm{Mg}$ alloy. The $\mathrm{NaF}$ and $\mathrm{Na}_{3} \mathrm{AlF}_{6}$ in the flux will significantly increase the sodium content of the alloy during the refining of $\mathrm{Al}-\mathrm{Mg}$ alloy or the recycling of $\mathrm{Al}-\mathrm{Mg}$ alloy. From this perspective, these two sodium salts should be avoided in the refining of alloys that have a limitation on sodium content, especially in the refining of $\mathrm{Al}$ alloys with high magnesium content in high-temperature brittleness is prone to occur.

\subsection{Effect of $\mathrm{Mg}$ Content on the Residual Content of Sodium in Al-Mg Alloys}

As Figure 2 shows, the sodium content in all alloys increases with the addition of $\mathrm{NK}-\mathrm{NaF}$ flux increasing. Nevertheless, there is a significant difference in increment. At the same addition level, the sodium content in $\mathrm{CP}-\mathrm{Al}$ (99.7\% purity) is the lowest, whereas the sodium content in $\mathrm{Al}-10 \mathrm{Mg}$ alloy is the highest. When the addition of flux increased from 0.3 to $10 \mathrm{wt} . \%$, the sodium content in $\mathrm{CP}-\mathrm{Al}$ increased from 1.4 to $31.4 \mathrm{ppm}$. When $0.3 \mathrm{wt} . \% \mathrm{NK}-\mathrm{NaF}$ flux was added, the sodium content of $\mathrm{Al}-10 \mathrm{Mg}$ alloy was $35.1 \mathrm{ppm}$, which was 1.4 and 4.1 times that of $\mathrm{Al}-5 \mathrm{Mg}$ alloy and $\mathrm{Al}-2 \mathrm{Mg}$ alloy, respectively. When the addition of flux was increased to $10 \mathrm{wt} . \%$, the sodium content of $\mathrm{Al}-2 \mathrm{Mg}, \mathrm{Al}-5 \mathrm{Mg}$ and $\mathrm{Al}-10 \mathrm{Mg}$ alloy increased to $113.8,172.1$ and $264 \mathrm{ppm}$, respectively.

The sodium increment in $\mathrm{CP}-\mathrm{Al}$ after refining with $\mathrm{NK}-\mathrm{NaF}$ flux is much smaller than $\mathrm{Al}-\mathrm{Mg}$ alloys, as the sodium increment in $\mathrm{CP}-\mathrm{Al}$ was introduced by the reaction between $\mathrm{NaF}$ and $\mathrm{Al}$, whose equilibrium constant is much smaller than that between $\mathrm{NaF}$ and Mg. As shown in Figure 3, the residual sodium increases with the flux addition while the magnesium content decreases sharply, which further indicates that the increase in sodium in $\mathrm{Al}-2 \mathrm{Mg}$ alloy was mainly due to the reaction between $\mathrm{NaF}$ and $\mathrm{Mg}$. Therefore, fluxes containing $\mathrm{NaF}$ reduce the magnesium content whilst they increase the sodium content during the recycling of $\mathrm{Al}-\mathrm{Mg}$ alloys. 


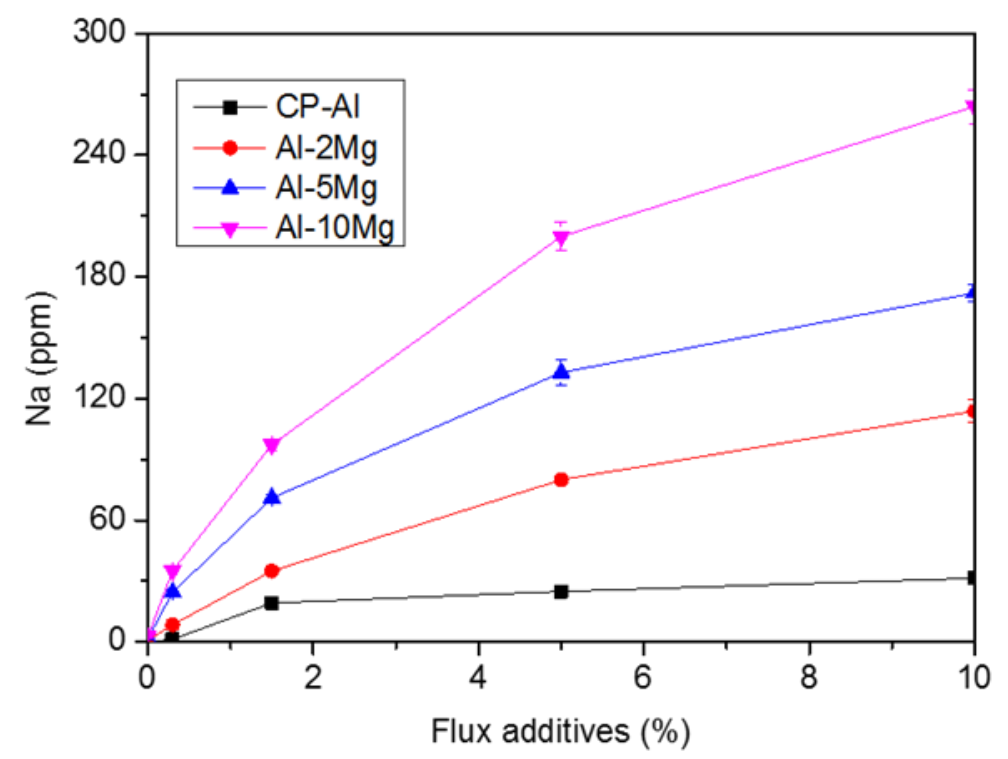

Figure 2. Effect of NK-NaF flux on the residual content of sodium in Al-Mg alloys.

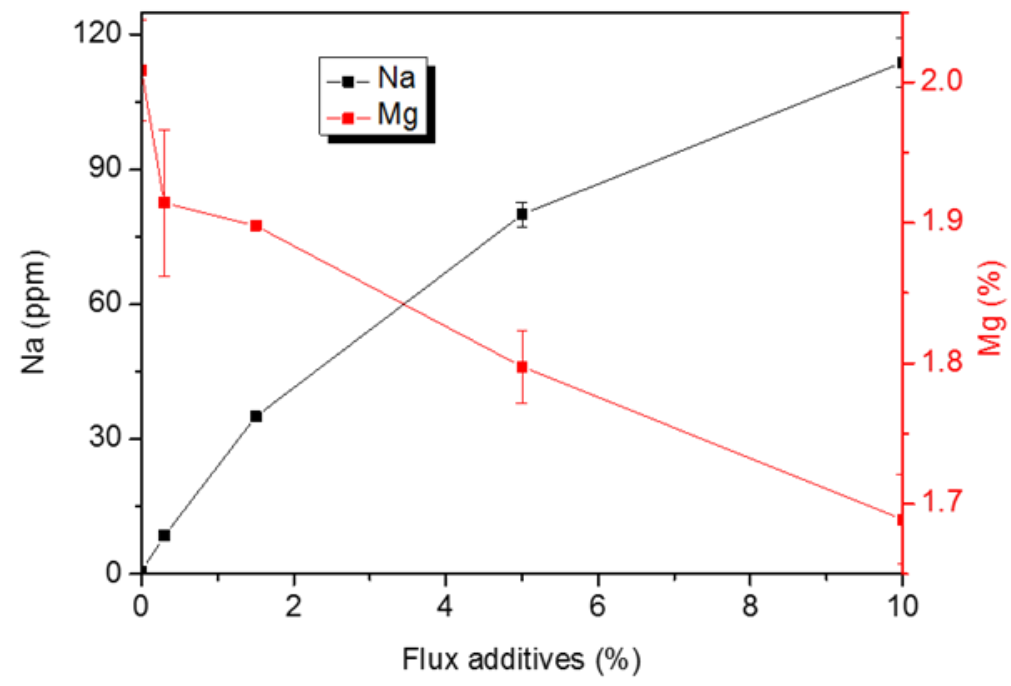

Figure 3. Effect of $\mathrm{NK}-\mathrm{NaF}$ flux on the contents of sodium and magnesium in $\mathrm{Al}-2 \mathrm{Mg}$ alloy.

At the same addition of flux, the sodium increment of $\mathrm{Al}-10 \mathrm{Mg}$ alloy was the largest, followed by $\mathrm{Al}-5 \mathrm{Mg}$ alloy, and $\mathrm{Al}-2 \mathrm{Mg}$ alloy was the smallest. The higher the magnesium content is, the higher the sodium increment in Al-Mg alloy. This is mainly due to the high concentration of magnesium facilitating the reaction toward the direction of sodium formation. The calculated phase diagram of Al-Mg-Na ternary alloy showed that the solubility of sodium in the alloy increases with the increase in magnesium content in $\mathrm{Al}-\mathrm{Mg}$ alloys [19]. In other words, the sodium introduced by the reaction was more likely to be dissolved in the alloy without gasification. Therefore, the Al-Mg alloy with higher magnesium content is more likely to accommodate sodium, and hence make the greater increment of sodium possible.

\subsection{The Distribution of Residual Sodium in Al-Mg Alloys}

Figure 4 shows the distribution of $\mathrm{Na}, \mathrm{Mg}$ and $\mathrm{Si}$ elements in the as-cast $\mathrm{Al}-2 \mathrm{Mg}$ alloy which was treated by $10 \mathrm{wt} . \% \mathrm{NK}-\mathrm{NaF}$ flux. It shows that the impurity element silicon was not completely dissolved in the $\mathrm{Al}-2 \mathrm{Mg}$ but formed as Si-rich particle. Due to the nonequilibrium solidification, most of the $\mathrm{Mg}$ stayed in solid solution during solidification, while a minority of $\mathrm{Mg}$ exist in the form of Mg-rich particles (as indicated by the arrow). 
It is worth noting that sodium aggregates and distributes in the form of Na-rich particles. However, the nature of Na-rich particles cannot be drawn from the EDS mapping.

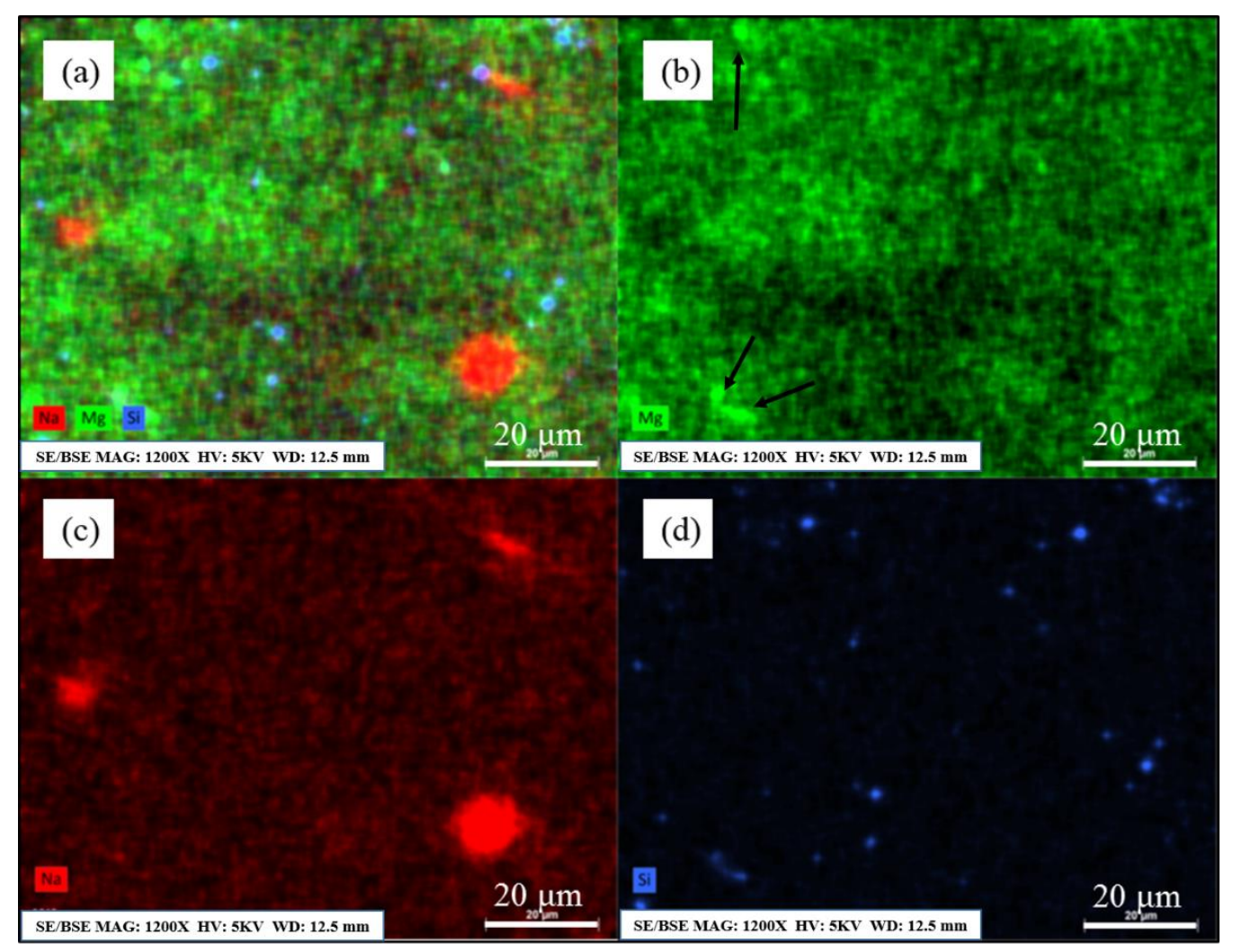

Figure 4. Elemental distribution of $\mathrm{Na}, \mathrm{Mg}$ and $\mathrm{Si}$ in as-cast $\mathrm{Al}-2 \mathrm{Mg}$ alloy (a) $\mathrm{Na}, \mathrm{Mg}$ and $\mathrm{Si}$; (b) $\mathrm{Mg}$; (c) Na; (d) Si.

The solubility of $\mathrm{Na}$ in liquid $\mathrm{Al}$ was found to be 0.115 at. \% at $1023 \mathrm{~K}$ and the maximum solubility of $\mathrm{Na}$ in solid $\mathrm{Al}$ to be less than 0.003 at. \% [20]. Na will enrich in the front of the solid-liquid interface during the solidification of the alloy. When the concentration of $\mathrm{Na}$ in the residual liquid phase is higher than 0.115 at. \%, the Na droplet will repel out of the residual liquid phase because the concentration of $\mathrm{Na}$ in the residual liquid phase is higher than the solubility of $\mathrm{Na}$ in liquid Al. Liquid sodium is immiscible with respect to liquid aluminum [20]. Due to the interfacial tension between the liquid aluminum and liquid sodium, the repelled sodium exists in the form of droplets in order to minimize the interfacial energy. Whether the sodium droplets are entrapped in the matrix depends on the size of the droplets and the growth rate of solid aluminum. The smaller the $\mathrm{Na}$ droplet is and the faster the solid grows, the easier it is for the droplet to attach to the solid. When the solid grows further, the Na droplet will be engulfed by the matrix. Such droplets are uniformly distributed in the matrix. During solidification the droplets are driven to preferentially collide in the residual liquid phase, and they have a large chance to coalesce and coarsen for further decrease in the interfacial energy. The big droplets remain in the liquid phase until the temperature is lowered enough [21]. Under the experimental conditions of this work, the temperature gradient of the alloy is large and the growth rate of solid phases is fast. So many small Na droplets, once formed, are uniformly distributed in the matrix and a few big Na droplets enrich in the last part of solidifying liquid.

Figure 5 shows the distribution of $\mathrm{Na}, \mathrm{Mg}$ and $\mathrm{Si}$ elements in the as-cast $\mathrm{Al}-5 \mathrm{Mg}$ alloy which was treated by $10 \mathrm{wt} . \% \mathrm{NK}-\mathrm{NaF}$ flux. All the regions showing high Mg content overlap with the regions enriching in $\mathrm{Si}$ and the trace impurity silicon and alloying element magnesium formed $\mathrm{Mg}_{2} \mathrm{Si}$ compound in the $\mathrm{Al}-5 \mathrm{Mg}$. Therefore, the regions containing very high $\mathrm{Mg}$ content are $\mathrm{Mg}_{2} \mathrm{Si}$ compounds and the regions that enriched less $\mathrm{Mg}$ are 
the $\mathrm{Al}_{3} \mathrm{Mg}_{2}(\beta)$ phase. Compared to $\mathrm{Al}-2 \mathrm{Mg}$ alloy, $\mathrm{Al}_{3} \mathrm{Mg}_{2}(\beta)$ phase precipitated during solidification in $\mathrm{Al}-5 \mathrm{Mg}$ alloy. Meanwhile, sodium exists in the form of Na-rich particles in the $\mathrm{Al}-5 \mathrm{Mg}$ alloy as the same as that of $\mathrm{Al}-2 \mathrm{Mg}$, and it was positioned near the $\mathrm{Al}_{3} \mathrm{Mg}_{2}(\beta)$ phase. Horikawa [9] found that silicon could inhibit the high-temperature brittleness of Al-Mg alloys with high magnesium content. That sodium could be attracted to the edge of $\mathrm{Mg}_{2} \mathrm{Si}$ in the presence of silicon reduces the amount of sodium at the grain boundary. However, in the production of wrought Al-Mg alloys, the addition of silicon is rarely used. It is therefore suggested to avoid sodium increment of the alloy by a cautious selection and use of salt flux.

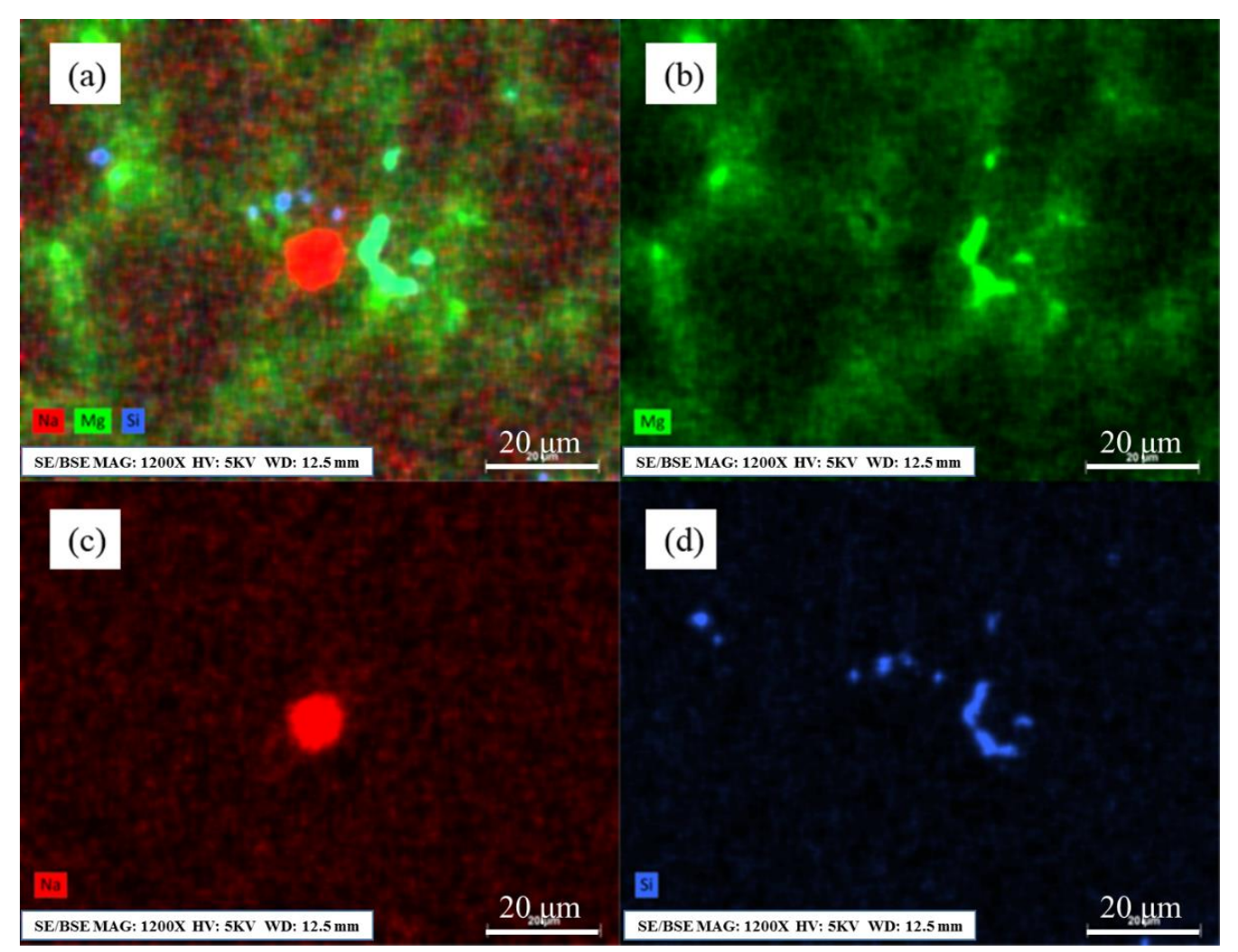

Figure 5. Elemental distribution of $\mathrm{Na}, \mathrm{Mg}$ and $\mathrm{Si}$ in as-cast $\mathrm{Al}-5 \mathrm{Mg}$ alloy (a) $\mathrm{Na}, \mathrm{Mg}$ and $\mathrm{Si}$; (b) $\mathrm{Mg}$; (c) $\mathrm{Na}$; (d) Si.

Figure 6 shows the distribution of $\mathrm{Na}, \mathrm{Mg}$ and $\mathrm{Si}$ elements in the as-cast $\mathrm{Al}-10 \mathrm{Mg}$ alloy with an addition of $10 \mathrm{wt} . \% \mathrm{NK}-\mathrm{NaF}$ flux. It can be seen that there was more $\mathrm{Al}_{3} \mathrm{Mg}_{2}(\beta)$ phase precipitated during solidification in $\mathrm{Al}-10 \mathrm{Mg}$ alloy. Similar to Al-5Mg alloy, the impurity element silicon was in the form of Si-rich particle in Al-10Mg alloy, whilst the sodium exists in the form of Na-rich particles beside the $\mathrm{Al}_{3} \mathrm{Mg}_{2}(\beta)$ phase. Different from Al-5Mg alloy, besides the large red spots shown in Figure 6, there are some small red spots scattered in the $\mathrm{Al}-10 \mathrm{Mg}$ alloy, which indicates that possibly a part of sodium is distributed in $\mathrm{Al}-10 \mathrm{Mg}$ alloy in the form of fine particles. It can be seen from Figure 7 that these fine sodium particles are located at the edge of the $\mathrm{Al}_{3} \mathrm{Mg}_{2}(\beta)$ phase. The EDS spectrum clearly shows $\mathrm{Na}, \mathrm{Mg}$ and $\mathrm{Al}$ in the particle, and the $\mathrm{Na}$ content is $16 \mathrm{wt} . \%$. 


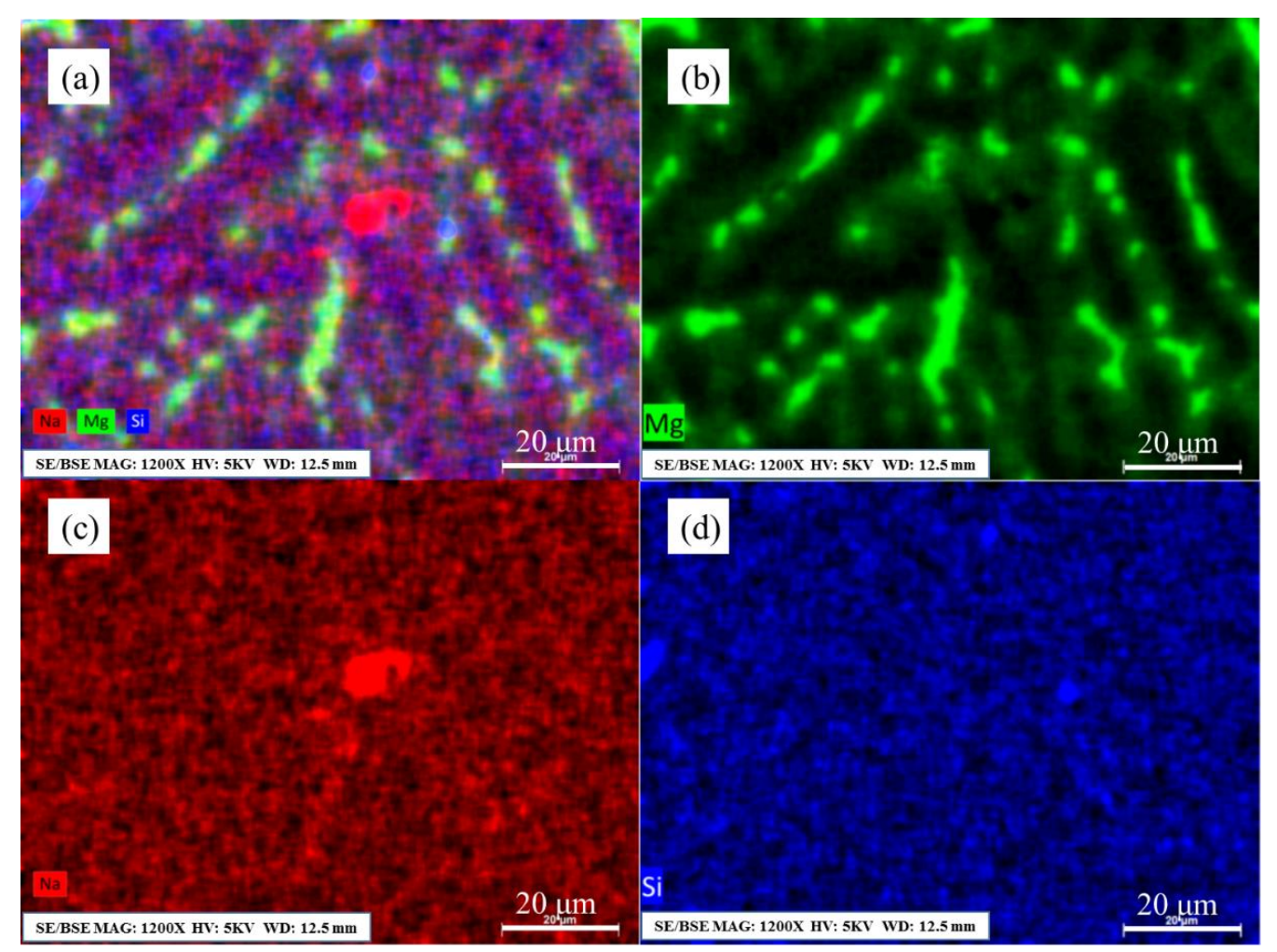

Figure 6. Elemental distribution of $\mathrm{Na}, \mathrm{Mg}$ and $\mathrm{Si}$ in as-cast $\mathrm{Al}-10 \mathrm{Mg}$ alloy (a) $\mathrm{Na}, \mathrm{Mg}$ and $\mathrm{Si}$; (b) $\mathrm{Mg}$; (c) $\mathrm{Na}$; (d) Si.
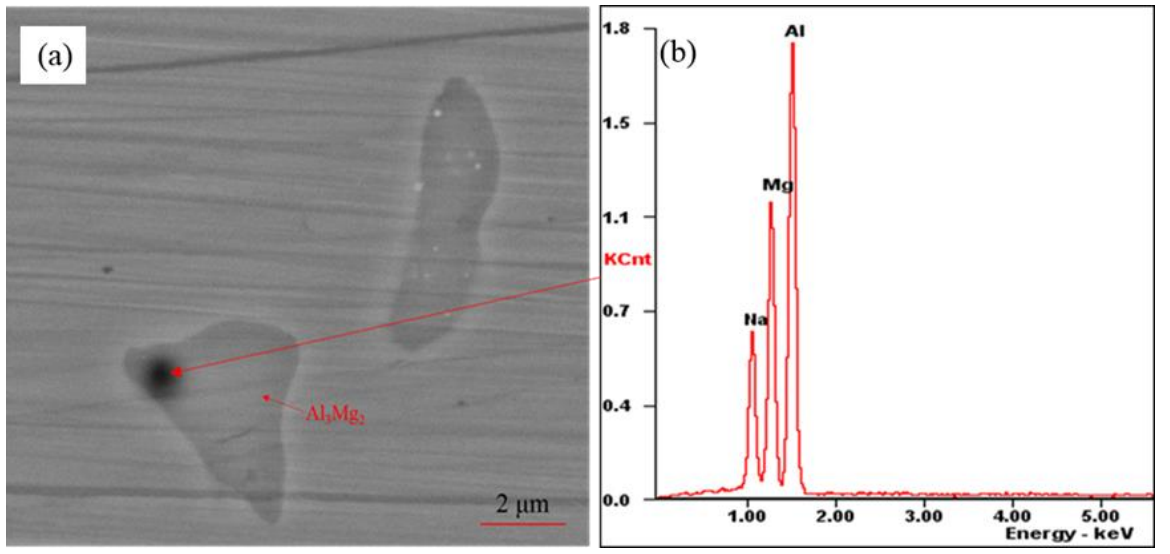

Figure 7. (a) SEM shows the $\mathrm{Na}$ and $\mathrm{Al}_{3} \mathrm{Mg}_{2}(\beta)$ phase; (b) the EDS result corresponding to the arrow.

As mentioned above, the Al-Mg alloy with higher Mg content picked up more Na. However, comparing Figures 4-6, we can see fewer Na-rich particles on the higher $\mathrm{Mg}$ content samples. That means that the higher the $\mathrm{Mg}$ content is, the higher content of $\mathrm{Na}$ is in solid solution in the matrix.

In summary, in $\mathrm{Al}-2 \mathrm{Mg}$ alloy, sodium aggregates in the form of Na-rich particles. Whilst in Al-5Mg alloy and $\mathrm{Al}-10 \mathrm{Mg}$ alloy, sodium aggregates mainly in the form of Na-rich particles near $\mathrm{Al}_{3} \mathrm{Mg}_{2}(\beta)$ phase. Furthermore, some small Na-rich particles are found distributed at the edges of the $\mathrm{Al}_{3} \mathrm{Mg}_{2}(\beta)$ phase in $\mathrm{Al}-10 \mathrm{Mg}$ alloy. Those findings are to some extent contradictory to the traditional theory that sodium segregates at the grain boundary and forms sodium film. The mechanism of high-temperature brittleness induced by the Na-rich particles is still unclear, and there is much work that needs to be done in the future. 


\section{Conclusions}

(1) When $\mathrm{Al}-10 \mathrm{Mg}$ melt was treated by $0.3 \mathrm{wt} . \%$ (the dosage generally used in industry) of fluxes with sodium component of $\mathrm{NaCl}, \mathrm{Na}_{3} \mathrm{AlF}_{6}$ and $\mathrm{NaF}$, respectively, the corresponding residual sodium content of the alloy is 7.9, 22.7 and $35.1 \mathrm{ppm}$. NaF and $\mathrm{Na}_{3} \mathrm{AlF}_{6}$ more easily cause the increase in sodium in Al-Mg alloys, and they should be avoided in the refining of $\mathrm{Al}-\mathrm{Mg}$ alloys with strict sodium content. In comparison, $\mathrm{NaCl}$ does not cause a significant increase in sodium in Al-Mg alloys.

(2) A sodium component in the flux, along with magnesium in the alloy, can cause increment of residual sodium content in alloys. The higher the magnesium content in the alloy, the more easily sodium is introduced and the higher the sodium increment. When $10 \mathrm{wt} . \%$ of NK-NaF flux was added, the sodium content of $\mathrm{Al}-2 \mathrm{Mg}, \mathrm{Al}-5 \mathrm{Mg}$ and $\mathrm{Al}-10 \mathrm{Mg}$ alloy was 113.8, 172.1 and $264 \mathrm{ppm}$, respectively.

(3) The sodium introduced by the fluxes presents as Na-rich particles in the $\mathrm{Al}-\mathrm{Mg}$ alloy, and mainly distributes near the $\mathrm{Al}_{3} \mathrm{Mg}_{2}(\beta)$ phase in the $\mathrm{Al}-\mathrm{Mg}$ alloy with a high magnesium content.

Author Contributions: Conceptualization, J.L. and C.H.; methodology, C.H., Q.L. and J.H.; software, C.H.; validation, Q.L., J.H. and Z.L.; formal analysis, C.H; investigation, C.H.; resources, J.L.; data curation, C.H.; writing — original draft preparation, C.H.; writing—review and editing, C.H. and J.L.; visualization, C.H.; supervision, J.L. and Z.L.; project administration, J.L.; funding acquisition, J.L. All authors have read and agreed to the published version of the manuscript.

Funding: This research was funded by The ISTCP grant No. 2015DFR50470.

Data Availability Statement: The data presented in this study are available on reasonable request from the corresponding author. The data are not publicly available due to privacy.

Acknowledgments: This work was supported by a grant from The ISTCP (2015DFR50470). The authors would like to thank Wenyan Yang for excellent technical support and Cong Li for critically reviewing the manuscript.

Conflicts of Interest: The authors declare no conflict of interest.

\section{References}

1. Utigard, T.A.; Friesen, K.; Rory, R.R. The properties and uses of fluxes in molten aluminum processing. JOM 1998, 50, 38-43. [CrossRef]

2. Luo, X.D.; Wu, X.F.; Zhang, Z.X.; Zhou, M.; Ding, Q.W.; Wang, J.C. Harmful Effect of Sodium and Calcium in Aluminum and Aluminum Alloys. Foundry Technol. 2015, 36, 2310-2314.

3. Chi, F.Q.; Wang, L.J.; Peng, X.L. Effect of Na on casting property of Aluminum alloys. Light Alloys Fabr. Technol. $2002,30,14-15$.

4. Talbot, D.E.; Ransley, C.E. The addition of bismuth to aluminum-magnesium alloys to prevent embrittlement by sodium. Metall. Trans. A 1977, 8, 1149-1154. [CrossRef]

5. Pascual, J.A. Emerging melt quality control solution technologies for aluminum melt. China Foundry 2009, 6, $358-365$.

6. Tremblay, S.; Desrosiers, L.; Levesque, D. Use of a binary salt flux of $\mathrm{NaCl}$ and $\mathrm{MgCl} 2$ for The Purification of Aluminum or Aluminum Alloys, And Method Thereof. U.S. Patent 7988763B2, 2 August 2011.

7. Li, C.; Li, J.G.; Mao, Y.Z.; Ji, J.C. Mechanism to remove oxide inclusions from molten aluminum by method solid fluxes refining. China Foundry 2017, 14, 233-243. [CrossRef]

8. Song, L.L.; Fu, G.S.; Chen, H.L.; Wang, H.S.; Lin, C.S. Purification of NaCl-KCl Based Inclusion Removal Flux on A356 Aluminum Alloy Melt and Structure and Properties after Purification. Mater. Mech. Eng. 2019, 43, 24-28.

9. Horikawa, K.; Kuramoto, S.; Kanno, M. Intergranular fracture caused by trace impurities in an Al-5.5 mol.\% Mg alloy. Acta Mater. 2001, 49, 3981-3989. [CrossRef]

10. Lynch, S.P. Comments on "Intergranular fracture caused by trace impurities in an Al-5.5 mol\% Mg alloy". Scr. Mater. 2002, 47, 125-129. [CrossRef]

11. Feng, L.; Sun, Y.M.; Zhao, X.L.; Wang, R.M.; Zhang, K.; Yang, J.Y. Existing form and harmful effects of sodium in Al-4.5\%Cu alloy. Trans. Nonferrous Met. Soc. China 2015, 25, 3553-3559. [CrossRef]

12. Sweet, E.D.; Lynch, S.P. Effects of alkali-metal impurities on fracture toughness of 2090 Al-Li-Cu extrusions. Metall. Mater. Trans. A Phys. Metall. Mater. Sci. 1996, 27, 3530-3541. [CrossRef]

13. Raja, R.R.; Torstein, A.; Utigard, T.A. Interfacial tension between aluminum and NaCl-KCl-based salt systems. Metall. Mater. Trans. B 1998, 29, 281-287. 
14. Friesen, K. Coalescence Behaviour and Inclusion Removal in Molten Aluminum Using Salt Fluxing; University of Toronto: Toronto, ON, Canada, 1996.

15. Baxmann, K.; Bornand, J.; Leconte, B. Impact of purification methods on inclusion and melt loss. Light Metals TMS-AIME 1977, 2, 191-206.

16. Friedrich, B.; Marcus, G.; Joachim, K.; Alexander, A. Improved Aluminium Recovery at Recycling Plants by integrated Slag Refining. In Proceedings of the European Metallurgical Conference, Friedrichshafen, Germany, 18-21 September 2001; Volume 2, pp. 121-139.

17. Sydykov, A.; Friedrich, B.; Arnold, A. Impact of parameter changes on the aluminum recovery in a rotary kiln. In Proceedings of the Sessions, TMS Annual Meeting, Warrendale, PA, USA, 17-21 February 2002; pp. 1045-1052.

18. Wang, X.; Peterson, R.D.; Richards, N.E. Dissolved metals in cryolitic melts. Essent. Read. Light Met. Alum. Reduct. Technol. 1991, 2, $49-56$.

19. Abdessameud, S.; Medraj, M. Understanding the hydrogen storage behavior of promising Al-Mg-Na compositions using thermodynamic modeling. Mater. Renew. Sustain. Energy 2016, 5, 7. [CrossRef]

20. Zhang, S.J.; Han, Q.Y.; Liu, Z.K. Thermodynamic modeling of the Al-Mg-Na system. J. Alloys Compd. 2006, 419, 91-97. [CrossRef]

21. Uhlmann, D.R.; Chalmers, B.; Jackson, K.A. Interaction Between Particles and a Solid-Liquid Interface. J. Appl. Phys. 1964, 35, 2986-2993. [CrossRef] 